\title{
Meningkatkan Kemampuan Kognitif Anak pada Pembelajaran Sains Melalui Metode Eksperimen
}

\author{
Zulfa Fauziah $^{1}$, Yuyun Yulianingsih ${ }^{2}$, Syamiyah $^{3}$ \\ 1,2,3Pendidikan Islam Anak Usia Dini, Universitas Islam Negeri Sunan Gunung Djati \\ Bandung \\ Jalan Soekarno Hatta Kel. Cimencrang, Gedebage Kota Bandung, Jawa Barat, Indonesia \\ Email: zulfafauziah018@gmail.com¹,Yuyunyulianingsih67@gmail.com², \\ adesyamiyah@gmail.com ${ }^{3}$
}

\section{Naskah diterima: 18 Desember 2019, direvisi: 11 Februari 2019, diterbitkan: 30 Maret 2019}

\begin{abstract}
Abstrak
Penelitian ini bertujuan untuk meningkatkan kemampuan kognitif anak pada pembelajaran sains melalui metode eksperimen di kelompok B. Penelitian menggunakan pendekatan mixed methods. Jenis penelitian adalah penelitian tindakan kelas kolaboratif. Subjek penelitian siswa kelompok B. Teknik pengumpulan data melalui observasi, wawancara dan dokumentasi. Teknik analisis data dilakukan secara deskriptif kualitatif dan kuantitatif. Hasil penelitian menunjukkan bahwa sebelum diterapkan metode eksperimen diperoleh rata-rata sebesar 39,24 dengan kriteria kurang sekali. Setelah penerapan metode eksperimen, kemampuan kognitif anak pada pembelajaran sains mengalami peningkatan setiap siklusnya. Hal ini dapat dilihat dari aktivitas guru pada siklus I diperoleh rata-rata sebesar 70\% dengan kriteria cukup dan pada siklus II diperoleh rata-rata sebesar 90\% dengan kriteria sangat baik, sedangkan aktivitas anak pada siklus I diperoleh rata-rata sebesar 65,39\% dengan kriteria cukup dan pada siklus II diperoleh rata-rata sebesar 84,62\% dengan kriteria baik. Selain itu, kemampuan kognitif anak pada pembelajaran sains pada siklus I diperoleh rata-rata sebesar 54 dengan kriteria kurang dan pada siklus II diperoleh rata-rata sebesar 76,04 dengan kriteria baik. Dengan demikian penerapan metode eksperimen dapat meningkatkan kemampuan kognitif anak pada pembelajaran sains di kelompok B.
\end{abstract}

Kata kunci: kemampuan kognitif, metode eksperimen, pembelajaran sains

\author{
Abstract \\ This study aims to improve children's cognitive abilities in science learning through experimental methods in \\ group B. The study used the mixed methods approach. This type of research is collaborative classroom action
}


research. Research subjects in group B. Techniques for collecting data through observation, interviews and documentation. Data analysis techniques were carried out in qualitative descriptive and quantitative. The results showed that before the experimental method was applied it was obtained an average of 39,24\% with very few criteria. After the application of the experimental method, children's cognitive abilities in science learning have increased every cycle. This can be seen from the activities of teachers in the first cycle obtained an average of $70 \%$ with sufficient criteria and in the second cycle obtained an average of $90 \%$ with very good criteria, while the activities of children in the first cycle obtained an average of 65,39\% with sufficient criteria and in the second cycle obtained an average of $84,62 \%$ with good criteria. In addition, children's cognitive abilities in science learning in the first cycle obtained an average of 54 with less criteria an in the second cycle obtained an average of 76,04 with good criteria. Thus the application of experimental methods can improve children's cognitive abilities in science learning in group $B$.

Key word: cognitive abilities, experimental methods, science learning

\section{Pendahuluan}

Pendidikan anak usia dini merupakan pendidikan yang sangat mendasar dan sangat menentukan bagi perkembangan anak di kemudian hari dan untuk menjamin keberlangsungan hidupnya agar lebih bermartabat. Sehingga dalam proses pembelajaran perlu mengembangkan seluruh aspek perkembangan salah satunya adalah perkembangan kognitif.

Menurut Wiyani (2014) perkembangan kognitif pada anak usia dini dapat diartikan sebagai perubahan psikis yang berpengaruh terhadap kemampuan berpikir anak usia dini. Dengan kemampuan berpikirnya anak mampu melatih ingatannya terhadap semua kejadian yang dialaminya, mampu memecahkan persoalan hidup yang dihadapinya serta mampu melakukan eksplorasi terhadap dunia sekitar melalui panca indranya.

Kognitif yang dimiliki oleh individu sangat berpengaruh pada kemampuannya dalam memperoleh pengetahuan agar dapat mengeksplorasikan dirinya dalam kehidupan seharihari. Seperti pendapat Yusuf (2017) bahwa kemampuan kognitif ialah kemampuan anak untuk berfikir lebih kompleks serta melakukan penalaran dan pemecahan masalah, berkembangnya kemampuan kognitif ini akan mempermudah anak menguasai pengetahuan umum yang lebih luas, sehingga ia dapat berfungsi secara wajar dalam kehidupan masyarakat sehari-hari. 
Salah satu pembelajaran yang diajarkan sejak usia dini adalah sains. Pengembangan sains pada anak usia dini merupakan kegiatan belajar melalui pengamatan, percobaan mengenai peristiwa yang terjadi dalam kehidupan sehari-hari yang banyak ditemukan oleh mereka.

Sains bagi anak usia dini menurut Carson (Nugraha: 2008) yaitu segala sesuatu yang menakjubkan, sesuatu yang ditemukan dan dianggap menarik serta memberi pengetahuan atau merangsangnya untuk mengetahui dan menyelidikinya. Sujiono (2015) mengemukakan bahwa pembelajaran sains adalah kegiatan belajar melalui pengamatan, penyelidikan dan percobaan untuk mencari tahu atau menemukan jawaban tentang kenyataan yang ada di dunia sekitar, yang dilakukan dengan menyenangkan dan menarik dilaksanakan melalui bermain.

Berdasarkan pengamatan pada kelompok B, peneliti menemukan adanya permasalahan yaitu kemampuan kognitif anak masih rendah khususnya pada pembelajaran sains, yaitu anak belum mampu melakukan eksplorasi seperti melakukan pengamatan dalam kegiatan sains, belum mampu memecahkan masalah seperti ketika guru menyuruh anak untuk mengkomunikasikan atau menceritakan kembali apa yang telah diamati dan diteliti, anak-anak terlihat kebingungan dan tampak kesulitan dalam menceritakan atau mengkomunikasikan peristiwa tersebut dan anak belum mampu menyebutkan sebab dan akibat dari kegiatan sains.

Begitu pun dalam metode yang digunakan oleh guru dalam pembelajaran sains kurang bervariatif. Pembelajaran yang berpusat pada guru dan hanya memberikan pembelajaran melalui majalah atau menggambar di papan tulis, sehingga metode tersebut membuat anak merasa bosan, kurang konsentrasi serta kurangnya antusias anak dalam pembelajaran, selain itu menyebabkan anak kurang diberi kesempatan untuk mencoba dan membangun pengetahuannya sendiri serta pengetahuan yang didapat anak tidak dapat bertahan lama dari ingatannya.

Dalam pembelajaran sains diperlukan suasana belajar yang menarik dan menyenangkan serta keterlibatan anak dalam pembelajaran. Dengan demikian anak akan mengingat kegiatan yang telah mereka lakukan dengan mudah. Salah kegiatan pembelajaran yang dapat melibatkan siswa yaitu dengan menggunakan metode eksperimen.

Metode eksperimen menurut Djamarah dan Aswan (2006) adalah cara penyajian pelajaran, di mana anak melakukan percobaan dengan mengalami sendiri sesuatu yang dipelajari. Pembelajaran melalui eksperimen, anak menjadi lebih aktif, guru berusaha 
membimbing, melatih dan membiasakan anak untuk terampil menggunakan alat, terampil merangkai percobaan dan mengambil kesimpulan.

Sujiono (2010) berpendapat bahwa metode eksperimen yaitu kegiatan pembelajaran melalui cara mengamati, meniru dan bereksperimen yang berlangsung secara berulang-ulang sehingga dapat melibatkan seluruh potensi dan kecerdasan anak. Dengan menggunakan metode eksperimen ini anak akan lebih mudah paham dan mengerti akan suatu permasalahan yang mereka hadapi daripada anak yang hanya menerima informasi.

Metode eksperimen memiliki beberapa kelebihan, seperti pendapat Anita (2007), diantaranya: (a) membangkitkan rasa ingin tahu anak, (b) membangkitkan sikap ilmiah anak, dan (c) membina kebiasaan belajar kelompok maupun individu.

Berdasarkan pemaparan di atas, maka peneliti tertarik melakukan penelitian yang berjudul "Meningkatkan Kemampuan Kognitif Anak pada Pembelajaran Sains Melalui Metode Eksperimen" Adapun tujuan dari penelitian ini adalah untuk meningkatkan kemampuan kognitif anak pada pembelajaran sains melalui metode eksperimen di kelompok B.

\section{Metodologi}

Penelitian ini menggunakan pendekatan mixed methods. Menurut Sugiyono (2018) mixed methods adalah suatu metode penelitian yang mengkombinasikan atau menggabungkan antara metode kuantitatif dan metode kualitatif untuk digunakan secara bersama-sama dalam suatu kegiatan penelitian sehingga diperoleh data yang lebih komprehensif, valid, realibel, dan objektif.

Metode penelitian yang digunakan yaitu penelitian tindakan kelas dengan pola kolaboratif. Desain yang digunakan dalam penelitian ini sebagaimana dikembangkan oleh Arikunto (2012), dilaksanakan dalam bentuk proses pengkajian bersiklus yang terdiri dari empat tahap yaitu perencanaan, pelaksanaan, pengamatan dan refleksi. Adapun desain penelitian pada siklus I dan II sebagai berikut.

a. Perencanaan, diantaranya menetapkan tujuan pembelajaran, menetapkan materi pembelajaran, menyiapkan alat dan bahan yang diperlukan, dan menyiapkan lembar penilaian.

b. Pelaksanaan, dilakukan sesuai dengan Rencana Pelaksanaan Pembelajaran Harian (RPPH) yang telah dibuat. 
c. Pengamatan, dilakukan bersamaan dengan proses pembelajaran.

d. Refleksi, hal ini akan berlanjut terus dan selalu diakhiri dengan evaluasi sejauh mana keberhasilan dalam proses strategi pengamatan dan keberhasilan dalam pembelajaran.

Metode dan desain penelitian tindakan kelas (PTK), secara visual dapat digambarkan sebagai berikut.

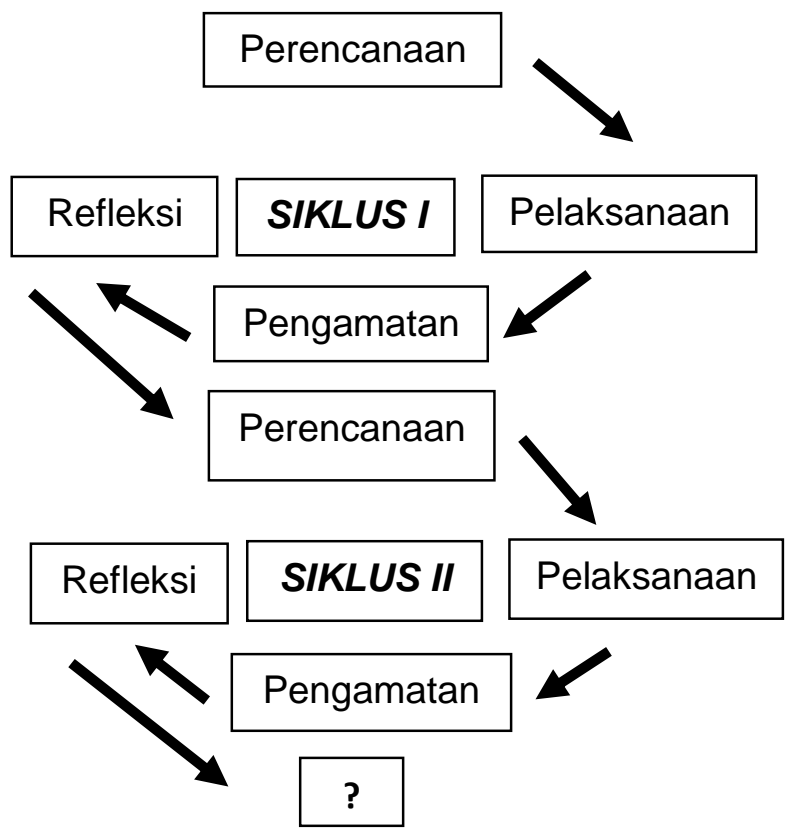

Gambar 1.Tahapan Pelaksanaan PTK

Sumber: Arikunto (2012)

Jenis data yang digunakan dalam penelitian ini adalah data kuantitatif dan kualitatif. Menurut Mahmud (2011: 146) data kuantitatif digunakan untuk memperoleh ketetapan atau lebih mendekati angka. Data bersumber dari hasil observasi kemampuan kognitif anak pada pembelajaran sains dengan penghitungan persentase. Sedangkan data kualitatif bersumber dari hasil observasi aktivitas guru dan anak, wawancara serta dokumentasi. Sumber penelitian menurut Mahmud (2011) terbagi menjadi dua macam yaitu sumber primer dan sumber sekunder. Sumber primer, yaitu anak kelompok B RA Al-Ikhlas dengan jumlah 12 anak. Sumber sekunder, yaitu kondisi objektif sekolah.

Penelitian dilakukan di kelompok B RA Al-Ikhlas, Desa Cintaraja Rt/Rw. 013/003 Kecamatan Singaparna Kabupaten Tasikmalaya. Waktu penelitian dilaksanakan pada semester ganjil tahun ajaran 2018/2019 dimulai pada bulan Juli sampai bulan Agustus 2018.

Data dikumpulkan melalui observasi, wawancara dan dokumentasi. Observasi menurut Dimyati (2013) adalah metode pengumpulan data penelitian dengan melalui pengamatan 
terhadap objek yang diteliti. Observasi ini dilakukan untuk memperoleh data tentang kemampuan kognitif anak pada pembelajaran sains serta aktivitas guru dan anak selama pembelajaran dengan menggunakan lembar observasi.

Sugiyono (2013) berpendapat bahwa wawancara merupakan pertemuan dua orang untuk bertukar informasi dan ide melalui tanya jawab, sehingga dapat dikontruksikan makna dalam suatu topik tertentu. Wawancara ini diajukan bagi guru untuk mengetahui kelebihan, kekurangan dan hambatan yang dialami dalam kemampuan kognitif anak pada pembelajaran sains dengan menggunakan lembar wawancara.

Menurut Sugiyono (2015) dokumentasi merupakan catatan peristiwa yang sudah berlalu. Dokumentasi yang digunakan yaitu dokumentasi gambar berupa foto atau video ketika proses pembelajaran berlangsung.

Analisis data dalam penelitian ini sebagai berikut.

1. Analisis Hasil Observasi Aktivitas Guru dan Anak

Data hasil observasi aktivitas guru dan anak dalam pembelajaran dianalisis menggunakan data deskriptif kualitatif, dengan menggunakan rumus:

$$
\mathrm{P}=\frac{f}{N} \times 100 \%
$$

(Sudijono, 2011)

Keterangan:

$\mathrm{P}=$ Persentase aktivitas guru dan anak

$\mathrm{f}=$ Banyaknya aktivitas guru dan anak yang muncul

$\mathrm{N}=$ Jumlah aktivitas keseluruhan

Setelah diperoleh hasil observasi aktivitas guru dan anak, maka dapat di interpretasikan pada skala kualifikasi berikut:

Tabel 1. Skala Kualifikasi Penilaian Aktivitas Guru dan Anak

\begin{tabular}{ccc}
\hline No. & Tingkat Penguasaan $(\%)$ & Predikat \\
\hline 1. & $86-100$ & Sangat Baik \\
2. & $76-85$ & Baik \\
3. & $60-75$ & Cukup \\
4. & $55-59$ & Kurang \\
5. & $\leq 54$ & Kurang Sekali \\
\hline \multicolumn{3}{c}{ Sumber: Purwanto (2006) }
\end{tabular}


2. Analisis Kemampuan Kognitif Anak pada Pembelajaran Sains

Data hasil observasi kemampuan kognitif anak pada pembelajaran sains sebelum dan sesudah penerapan metode eksperimen dianalisis menggunakan data kuantitatif dengan perhitungan persentase. Rumus yang digunakan yaitu:

Kemampuan kognitif anak pada pembelajaran sains

$$
\text { Kemampuan Kognitif }=\frac{\text { jumlah yang dicapai anak }}{\text { jumlah skor maksimal }} \times 100
$$

(Hayati, 2013)

Setelah diperoleh skor kemampuan kognitif pada pembelajaran sains setiap anak, hasilnya dapat diinterpretasikan pada skala kualifikasi sebagai berikut.

Tabel 2. Skala Kualifikasi Kemampuan Kognitif Anak pada PembelajaranSains

\begin{tabular}{ccc}
\hline No. & Tingkat Penguasaan $(\%)$ & Predikat \\
\hline 1. & $80-100$ & Sangat Baik \\
2. & $70-79$ & Baik \\
3. & $60-69$ & Cukup \\
4. & $50-59$ & Kurang \\
5. & $0-49$ & Kurang Sekali \\
\hline
\end{tabular}

Sumber: Syah (2013)

\section{Hasil dan Diskusi}

Pelaksanaan pra siklus ini dilakukan pada hari Kamis tanggal 26 Juli 2018, bertujuan untuk mengetahui kemampuan kognitif anak pada pembelajaran sains sebelum dilakukannya tindakan. Pra siklus dilaksanakan pada tema aku hamba Allah sub sub sub tema perut dengan kegiatan pembelajaran sains yaitu proses makanan di perut. Dalam kegiatannya guru hanya mengenalkan melalui metode tanya jawab dan memberikan gambar di papan tulis.Hasil observasi kemampuan kognitif anak pada pembelajaran sains pada pra siklus diperoleh ratarata sebesar 39,24 dengan kriteria kurang sekali.

Selain melakukan observasi selama pembelajaran, peneliti melakukan wawancara kepada guru kelompok B. Hasil wawancara yang dilakukan oleh peneliti yaitu kemampuan kognitif anak pada pembelajaran sains masih rendah, hal ini karena anak belum memahami tema yang disampaikan oleh guru. Selain itu metode yang digunakan pada pembelajaran hanya metode tanya jawab dan menggambar di papan tulis serta pada saat pembelajaran anak kurang antusias dan konsentrasinya belum terkondisikan. 
Dari hasil observasi dan wawancara tersebut menunjukkan bahwa kemampuan kognitif anak pada pembelajaran sains kurang sekali, disebabkan anak kurang bereksplorasi serta kurangnya pembelajaran yang melatih anak dalam pemecahan masalah. Hal ini diperlukan adanya perbaikan dalam pembelajaran berupa perlakuan metode yang tepat agar kemampuan kognitif anak pada pembelajaran sains dapat meningkat dengan baik, yaitu dengan metode eksperimen. Melalui metode ini anak terlibat langsung dalam kegiatan pembelajaran sehingga pengetahuan yang diperoleh akan bertahan lama, anak dapat bereksplorasi serta rasa ingin tahu anak terstimulus.

Proses pembelajaran menggunakan metode eksperimen untuk meningkatkan kemampuan kognitif anak pada pembelajaran sains, dapat dilihat dari aktivitas yang dilakukan oleh guru dan anak. Berikut gambaran aktivitas guru dan anak selama pembelajaran.

1. Aktivitas Guru dan Anak pada Siklus I

Siklus I terdiri dari dua tindakan. Tindakan pertama dilaksanakan pada tanggal $30 \mathrm{Juli}$ 2018 dan tindakan kedua pada tanggal 31 Juli 2018.

\section{a. Perencanaan}

Tahap perencanaan tindakan pada siklus ini yaitu:

1) Mendiskusikan susunan RPPH yang mengacu pada RPPM dan KD. Pembelajaran pada siklus pertama menggunakan tema aku hamba Allah, dengan tindakan pertama sub sub sub tema lidah dan tindakan kedua sub sub sub tema gigi.

2) Mempersiapkan lembar observasi aktivitas guru dan anak serta kemampuan kognitif anak pada pembelajaran sains menggunakan metode eksperimen.

3) Mempersiapkan alat dan bahan pembelajaran yang akan digunakan.

b. Tindakan

Pelaksanaan pembelajaran pada siklus I mempunyai 3 tahap, yaitu kegiatan awal, kegiatan inti dan kegiatan penutup. Kegiatan awal dimulai pada pukul 08.00 sampai 08.30 dengan kegiatan berbaris, berdo'a, satu per satu anak-anak membaca iqra, dilanjutkan dengan hafalan do'a sehari-hari. Guru menanyakan kabar anak, mengabsen kehadiran anak dan menyiapkan bahan-bahan yang dipakai di kegiatan inti. Setelah itu, guru melakukan tanya jawab mengenai tema pada hari itu. Kegiatan inti guru melanjutkan kegiatan belajar mengenai sains melalui eksperimen. Langkah-langkah dalam penerapan metode eksperimen pada pembelajaran sains yaitu

1) Guru menjelaskan tentang sains sesuai dengan tema yang diajarkan.

2) Guru menjelaskan alat dan bahan yang akan digunakan. 
3) Guru melakukan percobaan terlebih dahulu.

4) Anak melakukan eksperimen.

5) Anak menceritakan kembali kegiatan eksperimen.

6) Guru memberikan penguatan kegiatan yang telah dilakukan.

Kegiatan penutup guru melakukan evaluasi tentang pembelajaran yang sudah disampaikan kepada anak.

c. Observasi

Observasi ini berdasarkan data yang diperoleh dari lembar observasi dan dokumentasi. Hasil observasi aktivitas guru pada siklus I tindakan pertama sebesar 66,67\% dan tindakan kedua sebesar 73,33\% sehingga rata-rata siklus I sebesar 70\% pada kriteria cukup dan aktivitas anak pada tindakan pertama sebesar 61,54\% dan tindakan kedua sebesar 69,23\% sehingga rata-rata siklus I sebesar 65,39\% pada kriteria cukup.

d. Refleksi

Pada kegiatan pembelajaran di siklus I terdapat beberapa temuan diantaranya guru belum dapat mengkondisikan anak pada saat penyampaian tema, guru belum dapat mengkondisikan dan membimbing anak pada saat eksperimen dan anak belum dapat menceritakan kembali kegiatan yang telah dilakukan.

Untuk memperbaiki kekurangan yang terdapat pada siklus I, maka peneliti bersama guru kelompok B mengambil kesimpulan dan kesepakatan untuk melaksanakan siklus II.

2. Aktivitas Guru dan Anak pada Siklus II

Siklus II terdiri dari dua tindakan. Tindakan pertama dilaksanakan pada tanggal 1 Agustus 2018 dan tindakan kedua pada tanggal 2 Agustus 2018.

\section{a. Perencanaan}

Tahap perencanaan tindakan pada siklus ini yaitu:

1) Mendiskusikan susunan RPPH yang mengacu pada RPPM dan KD. Pembelajaran pada siklus pertama menggunakan tema aku hamba Allah, dengan tindakan pertama sub sub sub tema kulit dan tindakan kedua sub sub sub tema mata.

2) Mempersiapkan lembar observasi aktivitas guru dan anak saerta kemampuan kognitif anak pada pembelajaran sains menggunakan metode eksperimen.

3) Mempersiapkanalat dan bahanpembelajaran yang akandigunakan.

b. Tindakan 
Pelaksanaan pembelajaran pada siklus II mempunyai 3 tahap, yaitu kegiatan awal, kegiatan inti dan kegiatan penutup. Kegiatan awal dimulai pada pukul 08.00 sampai 08.30 dengan kegiatan berbaris, berdo'a, satu per satu anak-anak membaca iqra, dilanjutkan dengan hafalan do'a sehari-hari. Guru menanyakan kabar anak, mengabsen kehadiran anak dan menyiapkan bahan-bahan yang dipakai di kegiatan inti. Setelah itu, guru melakukan tanya jawab mengenai tema pada hari itu. Kegiatan inti guru melanjutkan kegiatan belajar mengenai sains melalui eksperimen. Langkah-langkah dalam penerapan metode eksperimen pada pembelajaran sains yaitu:

1) Guru menjelaskan tentang sains sesuai dengan tema yang diajarkan.

2) Guru menjelaskan alat dan bahan yang akan digunakan.

3) Guru melakukan percobaan terlebih dahulu.

4) Anak melakukan eksperimen.

5) Anak menceritakan kembali kegiatan eksperimen.

6) Guru memberikan penguatan kegiatan yang telah dilakukan.

Kegiatan penutup guru melakukan evaluasi tentang pembelajaran yang sudah disampaikan kepada anak.

c. Observasi

Observasi ini berdasarkan data yang diperoleh dari lembar observasi dan dokumentasi. Hasil observasi aktivitas guru pada siklus II tindakan pertama sebesar 86,67\% dan tindakan kedua sebesar 93,33\% sehingga rata-rata siklus II sebesar 90\% pada kriteria sangat baik. Gambaran peningkatan hasil observasi aktivitas guru dari siklus I sampai siklus II dapat dilihat berikut ini.

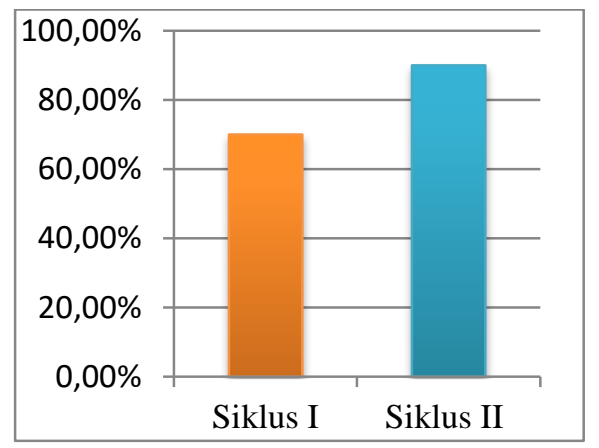

Gambar 2. Peningkatan Aktivitas Guru

Hasil observasi aktivitas anak pada siklus II tindakan pertama sebesar 76,92\% dan tindakan kedua sebesar $92,31 \%$ sehingga rata-rata siklus II sebesar $84,62 \%$ pada kriteria baik. 
Gambaran peningkatan hasil observasi aktivitas anak dari siklus I sampai siklus II dapat dilihat berikut ini.

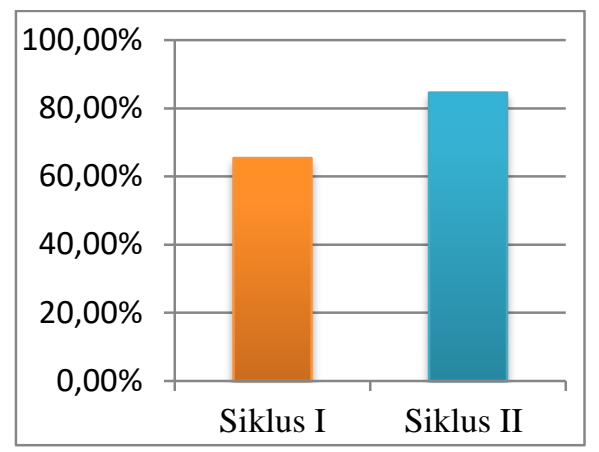

Gambar 3. Peningkatan Aktivitas Anak

d. Refleksi

Pada siklus II ini mengalami peningkatan yang sangat baik dari siklus I, adapun refleksi untuk siklus II yakni masih ada yang perlu diperbaiki, yaitu siswa belum sepenuhnya dapat melaksanakan kegiatan pembelajaran sains dengan semestinya, sehingga berpengaruh pada kemampuan kognitif anak. Sarannya guru harus terus memberi stimulus terlebih dahulu sebelum pada pembelajaran, selain itu memotivasi, membimbing serta keterlibatan anak dalam pembelajaran sains.

Selain data hasil observasi aktivitas guru dan anak selama pembelajaran, diperoleh data hasil observasi kemampuan kognitif anak pada pembelajaran sains. Pada siklus I tindakan pertama sebesar 48,61 dan tindakan kedua sebesar 59,38 sehingga rata-rata siklus I sebesar 54 pada kriteria cukup. Pada siklus II tindakan pertama sebesar 71,18 dan tindakan kedua sebesar 80,9 sehingga rata-rata siklus II sebesar 76,04 pada kriteria baik. Dari hasil analisis data di atas terjadi peningkatan kemampuan kognitif anak pada pembelajaran sains dari penelitian pra siklus, siklus I dan siklus II.

Perbandingan peningkatan kemampuan kognitif anak pada pembelajaran sains pra siklus, siklus I dan siklus II dapat digambarkan sebagai berikut. 


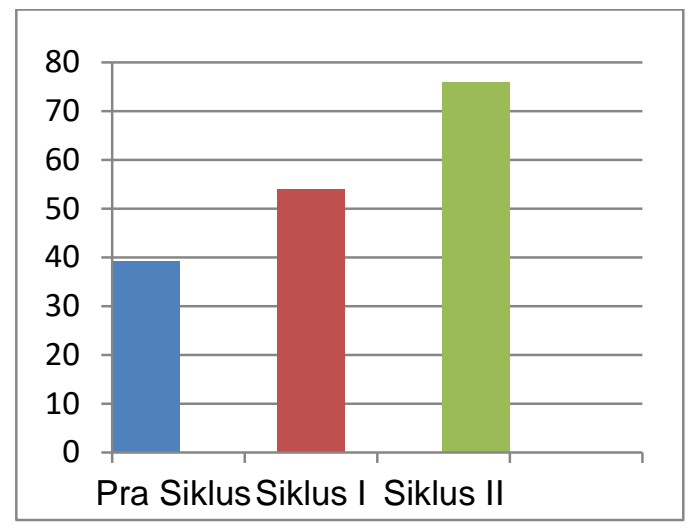

Gambar 4. Grafik Peningkatan Kemampuan Kognitif Anak pada Pembelajaran Sains

Selain peneliti mendapatkan hasil observasi selama pembelajaran, peneliti mendapatkan data hasil wawancara dari guru kelompok B yaitu kemampuan kognitif anak pada pembelajaran sains sebagian besar sudah berkembang dengan baik, anak sangat antusias dalam mengikuti pembelajaran melalui metode eksperimen, kelebihan dari metode eksperimen yaitu pembelajaran menjadi lebih terarah, anak-anak mendapatkan pengalaman secara langsung dan kekurangannya yaitu alat dan bahan yang digunakan terbatas dan membutuhkan waktu yang lama serta saran mengenai metode eksperimen untuk tindakan selanjutnya adalah alat/bahan yang mudah di cari, kegiatan sains yang lebih bervariatif serta keefektifan waktu.

Dari hasil observasi dan wawancara tersebut menunjukkan bahwa penggunaan metode eksperimen untuk meningkatkan kemampuan kognitif anak pada pembelajaran sains di kelompok B RA Al-Ikhlas Tasikmalaya telah berhasil dilaksanakan. Hasil observasi pra siklus mengenai kemampuan kognitif anak pada pembelajaran sains diperoleh rata-rata sebesar 39,24 dengan kriteria kurang sekali. Keadaan ini menunjukkan bahwa kemampuan kognitif anak pada pembelajaran sains kurang sekali.

Menurut Yusuf (2017) bahwa berkembangnya kemampuan kognitif akan mempermudah anak menguasai pengetahuan umum yang lebih luas, sehingga ia dapat berfungsi secara wajar dalam kehidupan masyarakat sehari-hari. Kemampuan anak dalam memperhatikan atau mengamati kejadian yang ada di sekitar anak harus diajarkan sejak usia dini dengan tujuan anak akan mendapat pengetahuan yang lebih dipercaya dan baik, maka perlu adanya metode pembelajaran. Sagala (2006) berpendapat bahwa guru harus menggunakan metode dan media yang bervariasi sehingga dapat mengurangi rasa bosan pada anak. 
Pada aktivitas guru di siklus I diperoleh rata-rata sebesar 70\% dengan kriteria cukup dan aktivitas anak diperoleh rata-rata sebesar 65,39\% dengan kriteria cukup. Keadaan ini menjelaskan bahwa dalam penerapan metode eksperimen, guru belum mampu mengkondisikan anak dan umumnya metode ini asing bagi anak. Seperti pendapat Schickedanz (Hartati, 2007)) bahwa jika suatu pengalaman belajar tidak memberikan kesempatan kepada anak untuk menciptakan pengetahuan baru, maka pembelajaran itu akan membosankan dan bila pengalaman itu terlalu asing bagi anak maka itu akan membuat anak cemas.

Saat melakukan eksperimen terdapat beberapa anak yang tidak melakukan eksperimen serta perlu bantuan dari guru. Hal ini penting bagi seorang guru untuk membimbing dan memotivasi kepada anak agar mampu mengikuti kegiatan eksperimen dengan baik sehingga dapat meningkatkan kemampuan kognitif pada pembelajaran sains. Abidin (2014) menjelaskan bahwa salah satu bentuk intervensi guru adalah membantu anak yang mengalami kesulitan ketika bermain.

Pada siklus II terjadi peningkatan yaitu aktivitas guru diperoleh rata-rata sebesar $90 \%$ dengan kriteria sangat baik dan aktivitas anak diperoleh rata-rata sebesar 84,62\% dengan kriteria baik.Ketercapaian pada siklus II ini dikarenakan metode yang diterapkan oleh guru dengan metode eksperimen sudah dapat dilakukan dengan baik sehingga berpengaruh pada aktivitas anak menjadi lebih baik.

Untuk kemampuan kognitif anak pada pembelajaran sains pada siklus I diperoleh ratarata sebesar 54 dengan kriteria kurang dan pada siklus II terjadi peningkatan diperoleh ratarata sebesar 76,04 dengan kriteria baik. Hasil tersebut dapat diketahui bahwa dengan penggunaan metode eksperimen dapat meningkatkan kemampuan kognitif anak pada pembelajaran sains. Seperti pendapat Winda (2010) bahwa tujuan dari kegiatan eksperimen bagi anak usia dini yaitu membangun anak dalam menggunakan kelima panca indranya dan memberi kesempatan anak untuk bereksplorasi dan menunjukkan kreativitasnya.

\section{Penutup}

Kemampuan kognitif anak di kelompok B RA Al-Ikhlas Tasikmalaya pada pembelajaran sains sebelum menggunakan metode eksperimen berdasarkan diperoleh nilai rata-rata sebesar 39,24 dengan kriteria kurang sekali. Penerapan metode eksperimen dalam meningkatkan kemampuan kognitif anak pada pembelajaran sains pada kelompok B di RA Al-Ikhlas Tasikmalaya pada setiap siklus mengalami peningkatan. Aktivitas guru pada siklus 
I diperoleh nilai rata-rata sebesar 70\% dengan kriteria cukup dan pada siklus II diperoleh nilai rata-rata sebesar 90\% dengan kriteria sangat baik, sedangkan aktivitas anak pada siklus I diperoleh nilai rata-rata sebesar 65,39\% dengan kriteria cukup dan pada siklus II diperoleh nilai rata-rata sebesar $84,62 \%$ dengan kriteria baik. Kemampuan kognitif anak pada pembelajaran sains di kelompok B RA Al-Ikhlas Tasikmalaya setelah menggunakan metode eksperimen pada setiap siklusnya mengalami peningkatan yang signifikan. Pada siklus I diperoleh nilai rata-rata sebesar 54 dengan kriteria kurang dan padasiklus II diperoleh nilai rata-rata sebesar 76,04 dengan kriteria baik. Bagi peneliti yang akan melakukan penelitian tindakan kelas dengan menggunakan metode eksperimen, hendaknya mempertimbangkan kembali kegiatan yang akan dilakukan. Materi yang akan disampaikan kepada anak usia dini harus disesuaikan dengan kebutuhan anak dan lebih disederhanakan kembali serta media yang akan digunakan lebih bervariatif.

\section{Daftar Pustaka}

Abidin, Y. (2014). Desain Sistem Pembelajaran dalam Konteks Kurikulum 2013. Bandung: PT. Refika Aditama.

Anita, S. (2007). Kelebihan dan Kelemahan Eksperimen. Jakarta: Erlangga.

Arikunto, S. (2012). Penelitian Tindakan Kelas. Jakarta: PT. Bumi Aksara.

Dimyati, J. (2013). Metodologi Penelitian Pendidikan dan Aplikasinya pada PAUD. Jakarta: Kencana.

Djamarah, S. B. dan Aswan, Z. (2006). Strategi Belajar-Mengajar. Jakarta: PT Rineka Cipta.

Hartati, S. (2007). Perkembangan Belajar Pada Anak Usia Dini. Jakarta: Departemen Pendidikan Nasional.

Hayati, T. (2013). Evaluasi Pembelajaran. Bandung: CV. Insan Mandiri.

Mahmud. (2011). Metodologi Penelitian Pendidikan. Bandung: CV Pustaka Setia.

Nugraha, A. (2008). Pengembangan Pembelajaran Sains Pada Anak Usia Dini. Bandung: Jilsi Foundation.

Purwanto, M. N. (2006). Prinsip-Prinsip dan TeknikEvaluasi Pengajaran. Bandung: PT. Remaja Rosdakarya.

Sagala, H. S. (2006). Konsep dan Makna Pembelajaran. Bandung: Alfabeta.

Sudijono, A.( 2011). Pengantar Evaluasi Pendidikan. Jakarta: Rajawali Pers.

Sugiyono. (2013). Metode Penelitian Kuantitatif, Kualitatif dan R \& D. Bandung: Alfabeta.

Sugiyono. (2015). Metodologi Penelitian Pendidikan. Bandung: Alfabeta.

Sugiyono. (2018). Metode Penelitian Kombinasi (Mixed Methods). Bandung: Alfabeta. 
Sujiono, Y. N. (2015). Metode Pengembangan Kognitif. Banten: Universitas Terbuka.

Sujiono. dkk. (2010). Bermain Kreatif Berbasis Kecerdasan Jamak. Jakarta: PT. Indeks

Syah, M. (2013). Psikologi Belajar. Jakarta: PT. Raja Grafindo Persada.

Winda, G. (2010). Metode Pengembangan Perilaku dan Kemampuan Dasar Anak Usia Dini. Jakarta: Universitas Terbuka.

Wiyani, N. A. (2014). Psikologi Perkembangan Anak Usia Dini.Yogyakarta: Gaya Media.

Yusuf, L. N. S. (2017). Psikologi Perkembangan Anak \& Remaja. Bandung: PT. Remaja Rosdakarya. 